\title{
Equity, a necessary consideration in the interface between health and the environment
}

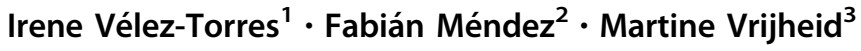

Received: 11 July 2018 / Accepted: 26 July 2018/Published online: 4 August 2018

(C) Swiss School of Public Health (SSPH+) 2018

The surface of the earth is our shared property, and none of us has more 'right' to occupy it than any other member of the human specie. And so, ultimately, at the time the limits of dispersion make themselves felt, there will be no recourse but to live together and support each other.

\section{Zygmunt Bauman - Society under siege}

The sixties were exemplary when it comes to the emergence of critical concepts on the capitalist model, that at the time espoused a rhetoric of development. Specifically, a dynamic academic field suggested to renew the vision on equity (Kuznets 1955; Pritchard 1969), taking distance from classic studies based on the evaluation of individual income or wealth distribution and on the differences in growth between countries (Deutsch 1975), generally associated with the use of the Gini coefficient (Atkinson 1970). Recently, social differences based on gender, race, ethnicity and generation have enriched the questions about inequity from transectorial and interdisciplinary fields.

The fact we're still asking about equity after more than half a century of empirical, theoretical and methodological

This editorial is part of the special issue "Environmental and health equity".

\section{Fabián Méndez}

fabian.mendez@correounivalle.edu.co

Irene Vélez-Torres

irene.velez@correounivalle.edu.co

Martine Vrijheid

martine.vrijheid@isglobal.org

1 School of Natural Resources and Environmental Engineering, Universidad del Valle, Calle 13 \# 100-00, Cali, Colombia

2 School of Public Health, Universidad del Valle, Calle 13 \# 100-00, Cali, Colombia

3 ISGlobal, Institute for Global Health, Barcelona, Spain debate implies that the conditions, structures, processes and determinants of inequity remain and on occasion deepen. A crucial issue in this long trajectory of debates concerns whether these determinants of inequity remain the same today as 50 years ago, or if we're witnessing an eternal recurrence of the different. If the latter is the case, the additional question that would arise is in what way is it different and what specific challenges do this new reality present.

In a different field, the book Silent Spring (Carson 2002) was published in the sixties and went down in history as the first critique on agricultural biotechnology, specifically analysing the negative impacts of pesticide use on biodiversity and environment. More recently, an important contribution was made by Guha (Guha and Martinez-Alier 1997) and Martinez-Alier (2002) when they pointed out that the distribution of environmental damage is concentrated in southern countries and in poor sectors of northern countries, thus configuring environmental damage segregation associated with poverty. Moreover, Bullard (1993) is an important benchmark in environmental sciences when proving the existence of a racialization of environmental impact. These reflections share a crucial consideration on the environment as our inhabiting niche, and a critical understanding of its degradation and differentiated impact among social groups, particularly those historically marginalized.

Environmental damage and its connections to health inequalities in the population have been the object of transdisciplinary analysis, beyond classical biomedical and epidemiologic scopes. Specifically, we're talking about the understanding of social determination in health, overcoming the paradigm of risk factors towards the understanding of historical processes where structural conditions and power differences generate inequalities that configure social "embodiment" processes of the disease throughout a lifespan in Krieger's (2013) terms. This supposes recognizing that human health cannot be seen as disconnected from the health of the rest of the living and non-living 
beings in the planet, and that therefore, in Bauman's words, the opportunity lies in the critical acknowledgement of our diversity (Bauman 2013).

It has been argued that we are in fact facing a convergence of crises: climate, environmental, economic, food and energy; that coexist and feed into each other. Nonetheless, faced with the complexity of a world that is in evident exhaustion, two inspiring ideas crosscut the new paradigm on environmental health. The first is that the earth is alive (Madhav and Guha 2013) and is not our resource pantry. Moreover, we think-feel with the territory (Escobar 2014), bear the responsibility to look after it and commit to care for any other living and non-living being. On the second hand, our wellbeing is not measured by our earning capacity or our income, but instead depends on our good living/Buen Vivir (D'Alisa et al. 2014), and in that daily construction, both individual and collective, crucial issues emerge related to gender, generation, race and ethnic equity.

We inhabit the planet with others from whom we can claim a radical otherness. Even still, as enunciated by Bauman, we share this world; we are forced neighbours in it. The differences, as an essential component to building our individual and collective identities, don't necessarily imply inequity. Instead, the physical, social and emotional borders we rise under the flags of difference but with the intention of wielding power, distance us from one another and lay the foundation for authoritarianism, racism and patriarchy. When I am not only different, but also superior, the difference becomes a frontier, that's just as created as it is real, and it is from that created distance that I impose myself on the subordinated other.

But these borders are porous, fragile and surmountable. Our task, as neighbours, is to identify these borders, explain them in order to revoke them, and from difference-but nor from superiority-engage in dialogue that allows us to co-inhabit this planet. Only in this way, from recognition and solidarity, will it be possible to heed the call of Haraway (2015) towards the construction of a robust biological-cultural-political-technological recuperation and recomposition of the Earth and all its current refuges.

This special issue constitutes a contribution on this path of construction of solidarity from academic understanding towards social action. The collection presents a variety of rigorous articles that face questions central to the interface between health, environment and equity, and they do so from different geographies, timelines, methods and (inter)disciplines.

\section{References}

Atkinson AB (1970) On the measurement of inequality. J Econ Theory 2(3):244-263

Bauman Z (2013) Society under siege. Wiley, Hoboken

Bullard RD (ed) (1993) Confronting environmental racism: Voices from the grassroots. South End Press, New York, p 245

Carson R (2002) Silent spring. Houghton Mifflin Harcourt, Boston, p 357

D’Alisa G, Demaria F, Kallis G (eds) (2014) Degrowth: a vocabulary for a new era. Routledge, Abingdon

Escobar A (2014) Sentipensar con la tierra. Nuevas lecturas sobre desarrollo, territorio y diferencia. Ediciones UNAULA, Medellín

Guha R, Martinez-Alier J (1997) Varieties of environmentalism. Essays North and South. Earthscan, London

Haraway D (2015) Anthropocene, capitalocene, plantationocene, chthulucene: making kin. Environ Hum 6:159-165

Krieger N (2013) Epidemiology and the people's health: theory and context. Oxford University, Oxford

Kuznets S (1955) Economic growth and income inequality. Am Econ Rev 45:1-28

Madhav G, Guha R (2013) Ecology and equity: The use and abuse of nature in contemporary India. Routledge, Abingdon

Martinez-Alier J (2002) The Environmentalism of the poor: a study of ecological conflicts and valuation. Edward Elgar, Cheltenham (with a new introduction. Oxford University Press, Delhi)

Pritchard RD (1969) Equity theory: a review and critique. Org Behav Hum Perform 4(2):176-211 